\title{
RELATO DE CASO: MENINGITE INFANTIL
}

Pôster

Autores deste trabalho:

Leticia Nascimento Machado: Acadêmico do Curso de Medicina da Faculdade de Medicina Uniāo dos Grandes Lagos - UNILAGO / São José do Rio Preto (SP)

Maria Clara Ferreira Melo: Acadêmico do Curso de Medicina da Faculdade de Medicina União dos Grandes Lagos - UNILAGO / São José do Rio Preto (SP)

Juliana Lenza Resende: Acadêmico do Curso de Medicina da Faculdade de Medicina Uniāo dos Grandes Lagos - UNILAGO / São José do Rio Preto (SP)

Mariana Rosa Queiroz: Acadêmico do Curso de Medicina da Faculdade de Medicina União dos Grandes Lagos - UNILAGO / São José do Rio Preto (SP)

Mariana Morais Olimpio: Acadêmico do Curso de Medicina da Faculdade de Medicina Uniāo dos Grandes Lagos - UNILAGO / São José do Rio Preto (SP)

Geraldo Gaspar Paes Leme Coutinho : Chefe do Departamento de Pediatria da Faculdade de Medicina Unilago -UNILAGO e Pediatra do Pronto Atendimento Infantil Unimed São José do Rio Preto (SP)

Humberto Brito Caballero: Diretor Médico do Pronto Atendimento Unimed São José do Rio Preto (SP)

Karina Del Arco: Enfermeira do Pronto Atendimento Infantil Unimed São José do Rio Preto (SP)

Área do Trabalho: Pediatria

Data da submissão:14/08/2018 às 19:21

\section{Justificativa}

Relatar casos

\section{Objetivo(s)}

Definir através do quadro apresentado pela criança e seguindo os critérios de inclusão e exclusão para o diagnóstico de meningite encontrados na literatura foi possível optar pelo uso de antibiótico.

\section{Método(s)}

Relato de caso na UNIMED de São José do Rio Preto. Verificar formas de conduzir a meningite bacteriana ou viral. Usou-se a bibliografia Schvartsman/ Cláudio. Pronto socorro/Cláudio Schvartsman, Amelia Gorete Reis, Sylvia Costa Lima Farhat. -2.edBarueri, SP: Manole,2013,

\section{Resultado(s)}

Relato de caso na UNIMED de São José do Rio Preto. Verificar formas de conduzir a meningite bacteriana ou viral. Usou-se a bibliografia Schvartsman/ Cláudio. Pronto socorro/Cláudio Schvartsman, Amelia Gorete Reis, Sylvia Costa Lima Farhat. -2.edBarueri, SP: Manole,2013, - RESULTADO SZ, 10 meses de idade, sexo feminino, chegou ao PA Unimed com febre há 5 dias, prostrada, alimentando-se pouco. Há 2 dias comendo e mamando pouco. Exame físico: hipoativa, gemente, momentos de 


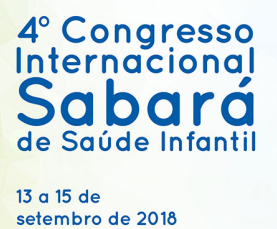

$4^{\circ}$ Congresso Internacional

de Saúde Infanti

setembro de 2018

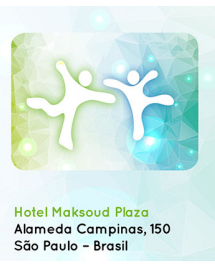

agitação. Fontanela anterior normotensa. Ausência de rigidez de nuca. Peso=8kgs. $T=$ 37, $8^{\circ} \mathrm{C}$. Destro $=97 \mathrm{mg} / \mathrm{dl}$. Exames, Hemograma: $\mathrm{Hb}: 12,1 \mathrm{~g} / \mathrm{dl}$; Leucócitos $=9370 \mathrm{~mm} 3$; bastonete:0, segmentado:57,4\%, Plaquetas: $165.000 \mathrm{~mm}$. Líquor: $v=3,5 \mathrm{ml}$; cor: incolor; aspecto: turvo; hemácias: 335 ; células: $743 / \mathrm{mm} 3$; células: neutrófilos:79\%, linfócitos:9\%, monócitos: $12 \%$ glicose: $41 \mathrm{mg} / \mathrm{dl}$, proteína total: $384 \mathrm{mg} / \mathrm{dl}$, uréia:14mg/dl, LDH desidrogenase lática: $81 \mathrm{U} / \mathrm{L}$. Bacterioscopia: ausência de bactérias e fungos. Cultura: não houve crescimento bacteriano. Tratamento inicial: $0,3 \mathrm{ml}$ de dipirona ev. $150 \mathrm{ml}$ de soro fisiológico 0,9\% ev em 40 minutos; $800 \mathrm{mg}$ de ceftriaxona ev. Alta no $5^{\circ}$ dia. DISCUSS\&\#256;O Nos EUA o bacterial meningitidis score (BMS) serve para identificar os casos de pouca possibilidade para apresentar meningite bacteriana nas crianças. No BMS não pode conter nenhum dos critérios: bacteriocopia positiva pela coloração de gram; contagem de neutrófilos no LCR > 1.000 células $/ \mathrm{ml}$; proteinorraquia $>80 \mathrm{mg} / \mathrm{dl}$; neutrófilos no sangue periférico > 10.000 células/ml; presença de crise convulsiva. Se encontrado um ou mais critérios do BMS, há risco aumentado de ser meningite bacteriana e a criança deve ser tratada como meningite bacteriana até o resultado das culturas. Nesse caso ocorreu uma proteinorraquia superior a $80 \mathrm{mg} / \mathrm{dl}$ e assim usamos ceftriaxona ev.

\section{Conclusão (ões)}

Este relato enfatiza a necessidade de diferenciação dos casos de meningite viral e bacteriana, como no BMS. Pelos critérios do BMS, foi possível a terapia com ceftriaxona endovenosa. 